\title{
KETAHANAN HIDUP DAN FEKUNDITAS LARVA Aedes aegypti (DIPTERA: CULICIDAE) PADA HABITAT SUBOPTIMAL
}

\author{
Rina Delfita \\ Tadris Biologi Fakultas Tarbiyah dan Ilmu Keguruan IAIN Batusangkar \\ Jalan Sudirman No. 137 Lima Kaum Batusangkar \\ Email: rinadelfita@iainbatusangkar.ac.id
}

\begin{abstract}
This study aims to provide general information about the survival and fecundity of Aedes aegypti in suboptimal habitats based on relevant research articles collected from 26 journal sources. A combination of three to five keywords was used to obtain the data. This journal is obtained from four electronic data bases, namely PubMed, Medline, Scopus and Google Schoolar, which were collected during 2017. The data were obtained by identifying, screening, matching the criteria that were intended (eligibility) and reviewing those articles. There were 83 journals identified and 56 journals reviewed. In addition, there were two local journals and 52 international ones. Journal review results show that larvae are able to live and complete their development into adulthood in suboptimal habitats. Stagnant sewer water that is clear and septic tanks are suboptimal larval habitats. Phosphorus is a major limiting factor in the presence of larvae in suboptimal habitats. Thus, manipulating the phosphorus content in ditches and septic tanks is one of the vector control strategies.
\end{abstract}

Key words: Suboptimal habitat, Aedes aegypti larvae, sewer water, septic tanks, survival, fecundity

\section{PENDAHULUAN}

Aedes aegypti L. (Diptera: Culicidae) merupakan vektor Demam Dengue (DD) dan Demam Berdarah Dengue (DBD), yang daerah penyebarannya sangat luas, hampir seluruh dunia antara latitude $45^{0} \mathrm{~N}$ and $35^{\circ} \mathrm{S}$ (Simard et al., 2005). Spesies ini termasuk spesies invasif yang penyebarannya sangat cepat dan luas (Paupy et al., 2010), karena daya adaptasinya yang tinggi (Troyo et al., 2007 ; Schneider et al., 2011), faktor lingkungan yang mendukung serta perilaku masyarakat yang kurang memperhatikan sanitasi dan mempunyai mobilitas yang tinggi (Vikram et al., 2015). Faktor lingkungan termasuk iklim (curah hujan), perilaku masyarakat yang sulit berubah dan sifat penanggulangan vektor yang tidak berkelanjutan membuat populasinya terus tinggi sehingga menyebabkan kasus penyakit Dengue tetap tinggi dari tahun ke tahun.
Ae. aegypti sangat bersifat thropophilic dan larva hidup pada kontainer yang terkait erat dengan manusia (Bar \& Andrew, 2012), seperti tempat penyimpanan air, kaleng-kaleng bekas, ban bekas, lubanglubang kayu, pot bunga dan lain-lain. Ae. aegypti cenderung mendominasi di daerah perkotaan yang padat penduduknya (Vikram et al., 2015). Kecenderungan nyamuk ini ditemukan di perkotaan dan pemukiman padat (Braks, 2006 ; Bagny Beilhe et al., 2013; Harrington et al., 2005; Madzlan et al., 2017). Nyamuk ini berkembang biak dengan cepat dalam wadah buatan yang digunakan untuk penyimpanan air dan segala jenis cangkir atau kendi terabaikan yang mengandung air tawar (Vikram et al., 2015). Belum diinformasikan mengenai kemampuan larva untuk bertahan hidup pada habitat sub optimal, seperti air yang tercemar. 
Beberapa studi lingkungan yang berbeda telah dilakukan pada Ae. aegypti, termasuk karakterisasi wadah yang paling produktif, yang bervariasi antar daerah, serta variasi dalam analisis genetik komunitas bakteri di habitat kontainer nyamuk(Ponnusamy et al., 2008) dan pemodelan kelimpahan dalam wadah tanah dan tangki air hujan di bawah skenario perubahan iklim (Kearney et al., 2009). Sehubungan dengan sumber makanan, beberapa penelitian menunjukkan bahwa masukan detritus adalah salah satu sumber energi utama untuk larva $A e$. aegypti di habitat akuatik. Telah terungkap bahwa kelimpahan bakteri berkurang oleh aktivitas makan Ae. triseriatus (Ma, Huang, \& Leng, 2016). Cyanobacteria tampaknya memiliki peran penting dalam diet, terbukti dari lambung $A e$. aegypti memiliki konsentrasi tinggi dari mikroorganisme fitoplankton ini. Selain detritus halus, bakteri, dan alga, sumber makanan lain untuk spesies Aedes dalam wadah pembiakan adalah jamur dan protozoa (Ye et al., 2016). Jika tidak, beberapa penelitian telah mencoba untuk membandingkan variabel ekologi yang dapat mengganggu pembentukan habitat untuk tahap belum dewasa dari spesies ini (Dom and Ahmad, 2013). Pada spesies culicide lainnya beberapa hubungan ekologis telah ditemukan untuk spesies Culex. Gardner et al., (2013) menyatakan amonia, nitrat, dan daerah semak kecil yang mengelilingi cekungan tangkapan perkotaan Chicago sebagai prediktor positif kelimpahan larva Culex tinggi, sedangkan $\mathrm{pH}$ dan area semak berbunga tampaknya berkorelasi negatif dengan larva di kolam yang terletak di habitat padang rumput Jerman. Belum diinformasikan mengenai kelimpahan larva Aedes pada habitat sub optimal, seperti air selokan dan septik tank dimana fosfor dan amoniak tinggi dan atau lebih rendah dari habitat optimalnya.

Penelitian ini bertujuan memberikan informasi kemungkinan larva Aedes aeegypti bisa bertahan hidup di daerah pemukimam padat khususnya pada air selokan dan septik tank. Penelitian ini meriview artikel tentang ketahanan larva pada tempat perindukan air kotor/sub optimal, perilaku larva dan fecunditas nyamuk dewasa Ae. Aegypti. Artikel yang direview diseleksi dari jurnal-jurnal terpilih dengan gabungan beberapa kata kunci "ketahanan, fekunditas, Ae. aegypty", habitat, nyamuk, sosioekonomi.

\section{METODE PENELITIAN}

Kombinasi 3 sampai lima kata kunci digunakan untuk menidentifikasi semua data publikasi tentang nyamuk Ae.aegypti terkait dengan ketahanan hidup dan fekunditasnya. Lima kata kunci tersebut adalah nyamuk Aedes aegypti, habitat sub optimal, ketahanan hidup, fekunditas dan sosioekonomi. Lima databes elektronik digunakan dalam mencari kata kunci yaitu PubMed, MEDLINE, Scopus, dan Google Scholar selama tahun 2017. Hirarki untuk memutuskan pemilihan artikel berdasarkan (Sallam, Fizer, Pilant, \& Whung, 2017), diawali dari identifikasi, skreening artikel, eligibilitas jurnal dan pemutusan pengambilan jurnal untuk direview. Didapatkan 83 buah jurnal dari 26 sumber jurnal yang memenuhi kriteria kata kunci yang telah ditetapkan tersebut (Tabel 1). Dari 83 jurnal tersebut yang dilanjutkan untuk direview adalah 46 jurnal. Lima buah jurnal lokal dan 41 buah jurnal internasional. 
Tabel 1. List jurnal 20 jurnal yang diriview

\author{
Journal of Medical Entomology \\ Jurnal Biotek Medisiana Indonesia \\ Jurnal e-Biomedik (eBM) \\ Jurnal Kesehatan Taduluko \\ Jurnal Kesehatan Masyarakat Indonesia \\ SEL \\ Acta Tropica \\ Evolution \\ Journal of Vector Ecology \\ Environmental Research \\ Indian J Med Res \\ Infection, Genetics and Evolution \\ Physiological Entomology \\ Parasites \& Vectors \\ Journal of Vector Ecology \\ Journal Applied Environment. Biol. Sci. \\ Southeast Asian Journal Trop Med Public Health \\ Journal Vector Borne Disease \\ Rev Saúde Pública \\ Tanzania Journal of Health Research \\ Journal of the American Mosquito Control Association \\ Indian J Medical Research \\ Journal of Experimental Biology \\ Microbial Ecology \\ Jurnal Veteriner
}

Data diambil dari tahun 2004-2017

\section{HASIL DAN PEMBAHASAN}

\section{Karakteristik habitat sub optimal Aedes aegypti}

Habitat suboptimum larva adalah habitat atau tempat hidup larva dimana kondisi habitat memiliki kondisi yang terbatas (tidak optimum untuk pertumbuhannya) baik makanan, suhu, kandungan kimia dan oksigen terlarutnya. Kebanyakan penelitian tentang Aedes aegypti terbatas kepada bagaimana pengaruh faktor lingkungan terhadap pekembangan dan populasinya pada air bersih, seperti faktor makanan dan suhu. Larva Ae. aegypti diketahui toleran pada suhu $10^{\circ} \mathrm{C}$ (Chang, Err-Lieh Hsu, Hwa-Jen Teng., 2006) dan berkembang lebih cepat pada suhu $25-30^{\circ} \mathrm{C}$, RH $70-90 \%$ (Couret, Dotson \& Benedict, 2014). Larva juga dapat bertahan hidup pada kondisi nutrisi yang minim (Perez \& Noriega, 2012 ; Perez \& Noriega, 2013; Perez \& Noriega, 2014) (Perez dan Noriega, 2012; Perez and Noriega, 2013) dan tanpa nutrisi sampai 18,5 - 20 hari (Arrivillaga dan Barrera, 2004). Beberapa tahun terakhir ini juga diketahui larva ditemukan dan berkembang pada air yang mengandung limbah $\mathrm{Cu}$ minim (Perez \& Noriega, 2012 ; Perez \& Noriega, 2013), air got, comberan, atau limbah abu-abu (Sudarmaja dan Mardihusodo, 2009).. Pada kondisi lingkungan seperti suhu dan keadaan lingkungan tidak menguntungkan maka telur juga bisa memasuki fase pharat instar 1 dan bisa bertahan mencapai 10 minggu (Farnesi, Martins, Valle, \& Rezende, 2009; Perez \& Noriega, 2013; Perez \& Noriega, 2012). Pharat instar 1 ini akan menetas dan 
Delfita, R. 2017. Ketahanan Hidup dan Fekunditas Larva Aedes Aegypti (Diptera: Culicidae) pada Habitat Suboptimal. Journal of Sainstek 9(2): 158-167

berkembang normal mencapai dewasa apabila lingkungan sudah mendukung untuk perkembangannya (Perez \& Noriega, 2013). Dengan demikian, nyamuk Ae. aegypti mempunyai toleransi yang luas terhadap berbagai perubahan faktor lingkungan dan kondisi habitat. Artinya, selain toleransinya yang luas terhadap faktor lingkungan seperti suhu dan kelembaban, tetapi juga toleansinya terhadap kondisi air tempat berkembang biaknya. Jadi, nyamuk Ae. aegypti tidak hanya berkembang biak pada air bersih tetapi juga pada air yang kotor (limbah sub optimal). Larva juga dapat berkembang pada air yang mengandung limbah $\mathrm{Cu}$, air got, comberan, atau limbah abu-abu.

Penelitian menunjukkan bahwa perlakuan larva dengan stress logam $\mathrm{Cu}$ mampu berkembang mencapai dewasa (Perez \& Noriega, 2013; Perez \& Noriega, 2012), meskipun tidak mencapai $100 \%$ dan hanya sedikit berpengaruh pada performan reproduksi betina. Pada musim penyebaran dengue, Ae. aegypti sering lebih memilih tempat kawin di container yang ada limbah padat/tercemar dan mampu menyelesaikan perkembangannya (Vikram et al., 2015). Air sabun (air tercemar) konsentrasi 0,5 g/L (Sudarmaja dan Mardihusodo, 2009; Qudsi, Muhamat, dan Rahman, 2012; Agustina, 2013), air leri (cucian beras) (Qudsi, Muhamat, dan Rahman, 2012), air septic tank (Burke et al., 2010; Mackay et al., 2009; Barrera et al., 2008) dan air kotoran sapi (Wurisastuti, 2013).

Habitat sub optimal larva Aedes aegypti pada septic tank diketahui pada $\mathrm{pH} 7,56$, suhu $26,83^{\circ} \mathrm{C}$, TDS $0,6-3,985$ p.p.t, konduktivitas 2,656 $\mu \mathrm{S}$ (Burke et al., 2010), pada drum diketahui pada suhu air $23,2-29,1^{\circ} \mathrm{C}$, konsentrasi nutrisi lebih rendah (yaitu: 35,66 dan 1989 kali lebih rendah untuk nitrat, ammonium dan SRP (fosfor reaktif terlarut) dibanding dengan nutrisi yang diobservasi di habitat lubang pohon (Hemme, Tank, Chadee, \& Severson, 2009). Garcia-Sánchez, Pinilla, \& Quintero, (2017) melaporan bahwa ditemukan pembeda faktor fisiko kimia dari septik tank yang ditemukan larva Ae. Aegypti dengan yang tidak adalah fosfat. Fosfat tinggi pada septik tank yang positif larva $(0,33)$. Cyanobakteria juga berkorelasi positif dengan kelimpahan larva.

Toleransi stadium imatur Aedes aegypti pada nutrisi sangat luas. Perlakuan larva dengan pembatasan nutrisi (3\% sukrosa) juga mampu melangsungkan perkembangan menjadi dewasa (Perez \& Noriega, 2013; Perez \& Noriega, 2012). Perkembangan stadium imatur bervariasi tergantung level nutrisi (perlakuan 0,025-1,6 $\mathrm{mg} /$ larva/hari). Level nutrisi yang tinggi/ menckupi diketahui perkembanganya cepat, yaitu 8,5 hari sedangkan kalau rendah nutrisinya bisa mencapai 18,5 hari. Diketahui juga bahwa larva Aedes aegypti juga bisa survive tanpa makanan tetapi berefek pada lamanya waktu perkembangan larva. Rata-rata resistensi terhadap kelaparan berkisar 20 hari (Arrivillaga \& Barrera, 2004).

Berdasarkan penelitian yang diuraikan di atas, jika dibandingkan kandungan air hujan yang langsung ditampung, air pada habitat ideal atau optimal larva (air pada lubang pohon), air pada habitat sub optimal larva (air drum, air septic tank), dan air selokan yang tanpa ada buangan veses diketahui pembeda utamanya adalah kehadiran atau ketidakhadiran fosfor. Air pada lubang pohon dan air pada drum mengandung fosfor, meskipun pada drum fosfor dalam jumlah yang kecil. Pada septic tank, fosfor kemungkinan sedikit lebih tinggi atau lebih rendah dibanding air drum atau air pada lubang pohon (tidak diukur, namun terlihat dari larva nyamuk Aedes aegypti bisa menyelesaikan perkembangnnya mencapai dewasa). Air selokan juga ada yang mengandung fosfor meskipun rendah. Oleh karena itu, apabila air selokan mengandung cukup fosfor (tidak terlalu tinggi) kemungkinan larva bisa hidup normal dan menyelesaikan perkembangannya mencapai nyamuk dewasa. Jadi, kemungkinan besar faktor pembatas utama air yang menjadi habitat larva Aedes aegypti adalah fosfor. Selain fosfor, faktor ketersediaan makanan juga menjadi faktor pembatas, dimana kelimpahan larva berkurang di tank yang populasi Cyanobakteria kurang. Artinya habitat sub optimal larva adalah air yang kadar fosfornya sedikit lebih tinggi atau lebih rendah 
Delfita, R. 2017. Ketahanan Hidup dan Fekunditas Larva Aedes Aegypti (Diptera: Culicidae) pada Habitat Suboptimal. Journal of Sainstek 9(2): 158-167

dibanding dengan kadar fosfor di lingkungan alaminya. Contohnya adalah air selokan yang tergenang yang sudah bening dan ternaung dan berlimpahanya Cyanobakteria menjadikan larva berkembang menjadi dewasa. Dengan demikian, pengontrolan selokan airnya tenang dan ternaung serta septik tank merupakan salah satu strategi penaggulangan vektor ini.

\section{Ketahanan Hidup Larva Aedes aegypti pada habitat sub optimal}

Larva nyamuk Aedes aegypti dapat hidup pada air got (Jacob, Pijoh, \& Wahongan, 2014; Hadi, Sigit, \& Agustina, 2009 ; Sayono, Qoniatun, \& Mifbakhuddin, 2011); mampu bertahan selama 6 hari dengan persentase $82,8 \%$ ) dan mampu mencapai pupa (Baharuddin \& Rahman, 2016) . Jacob, Pijoh, \& Wahongan, (2014) menyatakan larva mampu bertahan hidup 15 hari dengan jumlah nyamuk yang sama dari hari pertama sampai hari terakhir $(100 \%)$ pada air got. Pada air yang tercemar logam larva juga mampu bertahan dan mencapai dewasa, meskipun memberikan efek penurunan masa tubuh nyamuk dewasa, munculnya lipid storage netral, toleransi kelaparan berkurang, fekunditas berkurang dan toleransi kelaparan pada keturunan mereka juga rendah dibandingkan dengan individu-non stres logam (Perez \& Noriega, 2014). Ketahanan larva terhadap insektisida tergantung pada konsentrasi (Tomé, Pascini, Dângelo, Guedes, $\&$ Martins, 2014). Larva juga tahan pada kadar garam tertentu yang menunjukkan penyesuaian adaptif. Telur menetas dan larva berkembang menjadi dewasa pada kadar garam $(3,5,7,10,5$, 14 dan 17,5 \%o) (De Brito Arduino, Mucci, Serpa, \& De Moura Rodrigues, 2015).

Berdasarkan penelitian yang dipaparkan mengenai ketahanan hidup larva Ae. aegypti pada habitat suboptimal, diketahui bahwa larva Ae. aegypti mempunyai toleransi yang luas terhadap nutrisi dan lingkungan dengan hanya sedikit mempengaruhi waktu perkembangan dan fekunditasnya. Larva mampu hidup tanpa makan dalam waktu cukup lama (lebih kurang 20 hari), namun berefek pada lamanya waktu perkembangan. Apabila makanan berlimpah, maka waktu perkembangan cepat, bisa mencapai 8,5 hari dan begitu sebaliknya. Telur Aedes aegypti dalam kondisi lingkungan yang tidak menguntungkan, seperti suhu yang tinggi atau kelembaban yang terlalu rendah selama musim panas/kering akan mengalami masa tenang yang disebut dengan masa tenang (pharat instar 1) (meskipun tidak 100\% yang mengalami masa tenang). Perbedaan perkembangan larva dari telur yang mengalami masa tenang panjang dan pendek hanya sedikit.

Pada daerah tropis dan subtropik Ae. aegypti dihadapkan pada curah hujan yang tinggi dan pada musim panas menghadapi kekeringan. Pada musim hujan ketersediaan tempat kawin dan vegetasi yang berlimpah, serta kondisi kelembaban relatif tidak bisa diprediksi. Pada musim panas, ketersediaan sumber daya (nutrisi, tempat kawin dll) terbatas. Hal ini berpengaruh pada perkembangan Ae. aegypti. Namun, karena kondisi lingkungan yang sering tidak bisa diprediksi ini, gen-gen tertentu pada beberapa stadia perkembangan Ae. aegypti diekspresikan, guna mengahadapi lingkungan yang akan terjadi. Gen-gen yang diekspresikan adalah gen-gen yang bersifat fenotip plastisiti. Jadi, salah satu vaktor penyebarannya yang luas pada daerah tropis dan sub tropis ini adalah karena Ae.aegypti bersifat fenotip plastisiti. Dengan demikian, pengontrolan vektor ini yang paling efektif adalah dengan mengontrol dan memanipulasi habitatnya.

\section{Fekunditas Aedes aegypti pada habitat sub optimal}

Menurut Yulidar dan Wijaya, (2015); CDC, (2012), rata-rata waktu yang diperlukan sekali siklus hidup Aedes aegypti pada habitat optmum dari larva instar 3 (L3) menjadi pupa yaitu 45 jam 54 menit dan pupa menjadi dewasa 32 jam 41 menit. Lama hidup dewasa adalah 54 hari 4 jam 48 menit untuk betina dan jantan 42 hari 14 jam 24 menit. Sedangkan untuk aspek fekunditas, Aedes aegypti betina selama hidupnya rata-rata bertelur 16 kali dengan rata-rata jumlah telur yang dihasilkan mencapai 744 butir, tingkat daya tetas telur mencapai 80,09 (\%) dengan kemampuan ekdisis $75,95 \%$ dan eksklosi 
Delfita, R. 2017. Ketahanan Hidup dan Fekunditas Larva Aedes Aegypti (Diptera: Culicidae) pada Habitat Suboptimal. Journal of Sainstek 9(2): 158-167

90,67\%. Ratio jantan dengan betina dalam satu siklus bertelur adalah $54,54 \%$ banding $45,42 \%$.

Yulidar dan Wijaya, (2015) juga melaporkan bahwa setiap betina menghasilkan telur 62 telur dengan tingkat keseluruhan daya tetasnya $72 \%$. Waktu yang diperlukan untuk telur menetas menjadi larva adalah 4,5 hari. Waktu untuk pupation (P50) adalah 11,53 hari. Proporsi survivorships dewasa yang 0,69 untuk larva instar 1 ke pupa (P / I), 0,98 untuk pupa untuk dewasa dan keseluruhan 0,67 untuk instar 1 ke dewasa. Jantan muncul lebih cepat dari betina dengan waktu 12,83 dan $15,31 \mathrm{~d}$, masing-masingnya. Rata-rata kecepatan perkembangan $(\mathrm{V})$ menunjukkan bahwa jantan $(\mathrm{V}=0,081)$ berkembang lebih cepat dibandingkan betina $(\mathrm{V}=0.068)$. Rasio seks jantan / betina dewasa adalah 0,48, dan tidak berbeda signifikan dari rasio 1: 1. Harapan hidup dewasa 17,14 d untuk betina dan 9,59 d untuk jantan.

Faktor yang mempengaruhi pertumbuhan larva adalah nutrisi (Ray et al., 2009; Telang, Frame, \& Brown, 2007; Padmanabha et al. 2011), yang akan memiliki konsekuensi pada fekunditas dewasa (Perez \& Noriega, 2014; Perez \& Noriega, 2014), massa larva, massa dewasa, cadangan gizi dan profil produksi ekdisteroid (Telang, Frame, \& Brown, 2007). Faktor lain yang mempengaruhi pertumbuhan lainnya adalah suhu (Ma et al., 2016; Mohammed \& Chadee, 2011; Farjana, Tuno, \& Higa, 2012). Pada suhu $24-25^{\circ} \mathrm{C}$ keberhasilan telur menetas adalah $98 \%$, namun pada 34-35 ${ }^{0} \mathrm{C}$ telur menetas menurun menjadi $1,6 \%$. Larva Ae. Aegypti yang dipelihara pada suhu konstan menunjukkan pupasi pada hari ke- 4 dengan pupasi tertinggi terjadi pada suhu $30^{\circ} \mathrm{C}(78,4 \%)$ (Mohammed \& Chadee, 2011). Kadar oksigen terlarut (DO) dalam air mengakibatkan kelangsungan hidup larva berkurang dan waktu pengembangan yang lebih lama (Silberbush, Abramsky, \& Tsurim, 2015). Oksigen terlarut merupakan faktor yang signifikan mempengaruhi kelimpahan larva $C$. Annulirostris (Ma et al., 2016). GarciaSánchez, Pinilla, \& Quintero, (2017) melaporan bahwa ditemukan pembeda faktor fisiko kimia dari tempat perindukan yang ditemukan larva Ae. Aegypti dengan yang tidak adalah fosfat. Fosfat tinggi pada tempat perindukan yang positif larva (0,33). Cyanobakteria juga berkorelasi positif dengan kelimpahan larva.

Dari uraian di atas diketahui bahwa pertumbuhan dan lama waktu perkembangan dari larva dan fekunditas dewasa bervariasi tergantung kepada beberapa faktor, yaitu suhu, oksigen terlarut, makanan dan fosfat. Larva berkembang dengan cepat pada suhu, oksigen terlarut dan fosfat optimum dan akan terhambat pertumbuhan dan perkembangannya pada habitat yang kondisi suhu, oksigen terlarut, makanan dan fosfat kurang optimum (habitat suboptimun). Dengan kata lain, larva Ae. Aegypti yang hidup pada habitat suboptimum seperti ait tercemar dan septik tank yang memiliki kandungan fosfor dan oksigen terlarut yang tidak optimum, mampu berkembang menjadi nyamuk dewasa meskipun lama waktu perkembangannya masing-masing instar dan ukuran dewasanya berbeda. Nyamuk dewasa yang berasal dari larva yang hidup di habitat suboptimum juga memiliki fekunditas yang tidak berbeda dengan nyamuk dewasa yang berasal dari larva yang hidup di habitat optimumnya. Mackay et al., (2009) melaporkan bahwa nyamuk dewasa Ae. Aegypti memiliki ukuran tubuh lebih besar dibandingkan dengan ukuran tubuh nyamuk dewasa yang hidup di air bersih (habitat optimumnya). Fekunditas nyamuk dewasa yang hidup pada septik tank juga tidak jauh berbeda dengan dengan nyamuk dewasa yang hidup di air bersih. Habitat sub optimum tidak terlalu mempengaruhi fekunditasnya. Artinya, perkembangan Ae. Aegypti pada air bersih (habitat optimum) hampir sama atau sama baiknya dengan perkembangan $A e$. Aegypti pada air tercemar dan septik tank (habitat sub optimal).

Diantara faktor pembatas utama kehadiran nyamuk Ae. Aegypti pada habitat suboptimum adalah fosfor. Larva mampu berkembang menjadi dewasa dan dewasa bisa bereproduksi normal apabila kandungan fosfor habitat suboptimumnya sedikit lebih tinggi atau sedikit lebih rendah dari kandungan fosfor pada 
Delfita, R. 2017. Ketahanan Hidup dan Fekunditas Larva Aedes Aegypti (Diptera: Culicidae) pada Habitat Suboptimal. Journal of Sainstek 9(2): 158-167

air bersih yang menjadi habitat optimumnya. Belum dilaporkan berapa kandungan fosfor yang bisa larva Ae. Aegypti menyelesaikan perkembangannya menjadi dewasa pada air tercemar dan septik tank. Bagaimana karakteristik fisika dan kimia septik tank dan air tercemar juga belum dilaporkan.

\section{KESIMPULAN}

Nyamuk Ae. Aegypti memiliki kemampuan beradaptasi yang tinggi terhadap perubahan lingkungan. Nyamuk Ae. aegypti tidak hanya mampu hidup pada perindukan air jernih saja, tapi dapat juga bertahan hidup dan tumbuh normal pada habitat sub optimal seperti air selokan yang tergenang dan menjadi jernih dan pada septik tank. Faktor fisika kimia yang membatasi ketahanan hidup dan fekunditas larva nyamuk Ae. aegypti adalah fosfor. Air selokan memiliki karakteristik fosfat sedikit lebih rendah dibanding kandungan fosfat pada habitat normal, sedangkan septik tank adalah kebalikannya. Sehingga masyarakat perlu lebih waspada terhadap genangan air selokan yang jernih dan septik tank karena dapat menjadi habitat perindukan nyamuk Ae. aegypti. Kewaspadaan juga diberikan bagi pengelola program pengendalian vektor dan masyarakat dalam hal pemberantasan sarang nyamuk, tidak hanya pada air yang jernih saja. Dengan dermikian, disimpulkan bahwa pemanipulasian kandungan fosfor habitat sub optimal ini merupakan salah satu strategi pengendalian vektor.

\section{DAFTAR KEPUSTAKAAN}

Agustina E. 2013. Pengaruh Media Air Terpolusi Tanah terhadap Perkembangbiakan Nyamuk Aedes aegypti. Jurnal Biotik, 1(2), 103-107.

Arrivillaga J, \& Barrera R. 2004. Food as a limiting factor for Aedes aegypti in waterstorage containers. Journal of Vector Ecology, 29(1), 11-20.

Bagny Beilhe L, Delatte H, Juliano SA, Fontenille D, \& Quilici S. 2013.
Ecological interactions in Aedes species on Reunion Island. Medical and Veterinary Entomology, 27(4), 387-397. https://doi.org/10.1111/j.1365-

2915.2012.01062.x

Baharuddin A, \& Rahman R. 2016. Karakteristic Breeding Places dan Pertumbuhan Larva Aedes aegypti. Healthy Tadulako, 1(2).

Bar A, \& Andrew J. 2012. Seasonal Prevalence of Aedes aegypti Larvae in Agra. Research in Zoology, 2(3), 15-18. https://doi.org/10.5923/j.zoology.2012020 3.02

Barrera R, Amador M, Diaz A, Smith J, Munoz-Jordan JL, \& Rosario Y. 2008. Unusual productivity of Aedes aegypti in septic tanks and its implications for dengue control. Medical and Veterinary Entomology, 22(1), 62-69. https://doi.org/10.1111/j.1365-

2915.2008.00720.x

Braks MA. H, JSA. and LPL. 2006. NIH Public Access. Medical and Veterinary Entomology, 20(1), 53-59.

Burke RL, Barrera R, Lewis M, Kluchinsky T, \& Claborn D. 2010. Septic tanks as larval habitats for the mosquitoes Aedes aegypti and Culex quinquefasciatus in PlayaPlayita, Puerto Rico. Medical and Veterinary Entomology, 24(2), 117-123. https://doi.org/10.1111/j.1365-

2915.2010.00864.x

CDC. 2012. Mosquito Life Cycle Aedes aegypti. National Center for Emerging and Zoonotic Infectious Disease, 1-2.

Chang LH, Err- Lieh Hsu, Hwa-Jen Teng, C-M H. 2006. Differential Survival of Aedes aegypti and Aedes albopictus (Diptera: Culidae) Larvae Exposed to Low Temperatures in Taiwan. Jour. of Med. Entomol, 205 - 210.

Couret J, Dotson E, \& Benedict MQ. 2014. Temperature, larval diet, and density effects on development rate and survival of Aedes aegypti (Diptera: Culicidae). PLoS ONE, 9(2). https://doi.org/10.1371/journal.pone.0087 468 
Delfita, R. 2017. Ketahanan Hidup dan Fekunditas Larva Aedes Aegypti (Diptera: Culicidae) pada Habitat Suboptimal. Journal of Sainstek 9(2): 158-167

De Brito Arduino M, Mucci LF, Serpa LLN, \& De Moura Rodrigues M. 2015. Effect of salinity on the behavior of Aedes aegypti populations from the coast and plateau of southeastern Brazil. Journal of Vector Borne Diseases, 52(1), 79-87.

Dom NC, AH Ahmad, and RI. 2013. Habitat characterization of Aedes sp. breeding in urban hotspot area. In Social dan Behaviour Science (p. 100-109.).

Farjana T, Tuno N, \& Higa Y. 2012. Effects of temperature and diet on development and interspecies competition in Aedes aegypti and Aedes albopictus. Med Vet Entomol, 26(2), 210-217. https://doi.org/10.1111/j.13652915.2011.00971.x

Farnesi LC, Martins AJ, Valle D, \& Rezende, GL. 2009. Embryonic development of Aedes aegypti (Diptera: Culicidae): Influence of different constant temperatures. Memorias Do Instituto Oswaldo Cruz, 104(1).

Garcia-Sánchez DC, Pinilla GA, \& Quintero J. 2017. Ecological characterization of Aedes aegypti larval habitats (Diptera: Culicidae) in artificial water containers in Girardot, Colombia. Journal of Vector Ecology, 42(2), 289-297. https://doi.org/10.1111/jvec.12269

Gardner AM, Anderson TK, Hamer GL, Johnson DE, Varela KE, Walker ED, \& Ruiz MO. 2013. Terrestrial vegetation and aquatic chemistry influence larval mosquito abundance in catch basins, Chicago, USA. Parasites and Vectors, 6(1), 1-11. https://doi.org/10.1186/17563305-6-9

Hadi UK, Sigit SH, \& Agustina E. 2009. Habitat jentik Aedes aegypti (Diptera: Culicidae) pada Air Terpolusi di Laboratorium. In Prosiding Seminar Nasional Hari Nyamuk 2009 (pp. 1-13).

Harrington LC, Scott TW, Lerdthusnee K, Coleman RC, Costero A, Clark GG, ... Edman JD. 2005. Dispersal of the dengue vector Aedes aegypti within and between rural communities. The American Journal of Tropical Medicine and Hygiene, 72(2),
209-20. https://doi.org/72/2/209 [pii]

Hemme RR, Tank JL, Chadee DD, \& Severson DW. 2009. Environmental conditions in water storage drums and influences on Aedes aegypti in Trinidad, West Indies. Acta Tropica, 112(1), 59-66. https://doi.org/10.1016/j.actatropica.2009. 06.008

I Made Sudarmaja, SJM. 2009. Pemilihan Tempat Bertelur Nyamuk Aedes aegypti pada Air Limbah Rumah Tangga di Laboratorium. Jurnal Veteriner, 10(4), 205-207.

Jacob A, D Pijoh V, \& Wahongan. 2014. Ketahanan Hidup Dan Pertumbuhan Nyamuk Aedes spp Pada Berbagai Jenis Air Perindukan. Jurnal E-Biomedik (eBM), 2(3), 1-5.

Kearney M, Porter WP, Williams C, Ritchie S, \& Hoffmann AA. 2009. Integrating biophysical models and evolutionary theory to predict climatic impacts on species' ranges: The dengue mosquito Aedes aegypti in Australia. Functional Ecology, 23(3), 528-538. https://doi.org/10.1111/j.13652435.2008.01538. $\mathrm{x}$

Ma M, Huang M, \& Leng P. 2016. Abundance and distribution of immature mosquitoes in urban rivers proximate to their larval habitats. Acta Tropica, 163, 121-129. https://doi.org/10.1016/j.actatropica.2016. 08.010

Mackay AJ, Amador M, Diaz A, Smith J, \& Barrera R. 2009. Dynamics of Aedes aegypti and Culex quinquefasciatus in Septic Tanks. Journal of the American Mosquito Control Association, 25(4), 409-416. https://doi.org/10.2987/095888.1

Madzlan F, Dom NC, Zakaria N, Hasnan SNA, Tiong CS, \& Camalxaman SN. 2017. Profiling of dengue vectors breeding habitat at urban residential areas in shah alam, Malaysia. Serangga, 22(2).

Mohammed A, \& Chadee DD. 2011. Effects of different temperature regimens on the development of Aedes aegypti (L.) (Diptera: Culicidae) mosquitoes. Acta 
Delfita, R. 2017. Ketahanan Hidup dan Fekunditas Larva Aedes Aegypti (Diptera: Culicidae) pada Habitat Suboptimal. Journal of Sainstek 9(2): 158-167

Tropica, 119(1), 38-43. https://doi.org/10.1016/j.actatropica.2011. 04.004

Padmanabha H, Bolker B, Lord CC, Rubio C, \& Lounibos LP. 2011. Food availability alters the effects of larval temperature on Aedes aegypti growth. Journal of Medical Entomology, 48(5), 974-84. https://doi.org/10.1603/ME11020

Paupy C, Ollomo B, Kamgang B, Moutailler S, Rousset D, Demanou M, ... Simard F. 2010. Comparative Role of Aedes albopictus and Aedes aegypti in the Emergence of Dengue and Chikungunya in Central Africa. Vector-Borne and Zoonotic Diseases, 10(3), 259-266. https://doi.org/10.1089/vbz.2009.0005

Perez MH, \& Noriega FG. 2012. Aedes aegypti pharate 1 st instar quiescence affects larval fitness and metal tolerance. Journal of Insect Physiology, 58(6), 824-829. https://doi.org/10.1016/j.jinsphys.2012.03. 005

Perez MH, \& Noriega FG. 2013. Aedes aegypti pharate 1st instar quiescence: A case for anticipatory reproductive plasticity. Journal of Insect Physiology, 59(3), 318324.

https://doi.org/10.1016/j.jinsphys.2012.12. 007

Perez MH, \& Noriega FG. 2014. Sublethal metal stress response of larvae of Aedes aegypti. Physiological Entomology, 39(2), 111-119. https://doi.org/10.1111/phen.12054

Ponnusamy L, Xu N, Stav G, Wesson DM, Schal C, \& Apperson CS. 2008. Diversity of bacterial communities in container habitats of mosquitoes. Microbial Ecology, 56(4), 593-603. https://doi.org/10.1007/s00248-008-93796

Qudsi H, Muhamat dan Rahman A. 2012. Preferensi nyamuk Aedes sp. Dan Culex sp. Menggunakan media cair limbah rumah tangga di Banjarbaru. Biocientiae, $9(2), 40-47$.

Ray K, Mercedes M, Chan D, Choi CY, \& Nishiura JT. 2009. Growth and
Differentiation of the Larval Mosquito Midgut. Journal of Insect Science. https://doi.org/10.1673/031.009.5501

Sallam MF, Fizer C, Pilant AN, \& Whung PY. 2017. Systematic review: Land cover, meteorological, and socioeconomic determinants of aedes mosquito habitat for risk mapping. International Journal of Environmental Research and Public Health.

https://doi.org/10.3390/ijerph14101230

Sayono Qoniatun S, \& Mifbakhuddin. 2011. Pertumbuhan Larva Aedes aegypti pada Air Tercemar. Jurnal Kesehatan Masyarakat Indonesia, 7(1), 15-22.

Schneider JR, Chadee DD, Mori A, RomeroSeverson J, \& Severson DW. 2011. Heritability and adaptive phenotypic plasticity of adult body size in the mosquito Aedes aegypti with implications for dengue vector competence. Infection, Genetics and Evolution, 11(1), 11-16. https://doi.org/10.1016/j.meegid.2010.10. 019

Silberbush A, Abramsky Z, \& Tsurim I. 2015. Dissolved oxygen levels affect the survival and developmental period of the mosquito Culex pipiens. Journal of Vector Ecology. https://doi.org/10.1111/jvec.12186

Simard F, Nchoutpouen E, Toto JC, \& Fontenille D. 2005. Geographic distribution and breeding site preference of Aedes albopictus and Aedes aegypti (Diptera: culicidae) in Cameroon, Central Africa. Journal of Medical Entomology, 42(5), 726-731.

https://doi.org/10.1603/00222585(2005)042

Telang A, Frame L, \& Brown MR. 2007. Larval feeding duration affects ecdysteroid levels and nutritional reserves regulating pupal commitment in the yellow fever mosquito Aedes aegypti (Diptera: Culicidae). Journal of Experimental Biology, 210(5), 854-864. https://doi.org/10.1242/jeb.02715

Tomé HV, Pascini TV, Dângelo RA, Guedes RN, \& Martins GF. 2014. Survival and 
swimming behavior of insecticideexposed larvae and pupae of the yellow fever mosquito Aedes aegypti. Parasites \& Vectors, 7(1), 195. https://doi.org/10.1186/1756-3305-7-195

Troyo A, Calderón-Arguedas O, Fuller DO, Solano ME, Avendaño A, Arheart KL, ... Beier JC. 2008. Seasonal profiles of Aedes aegypti (Diptera: Culicidae) larval habitats in an urban area of Costa Rica with a history of mosquito control. Journal of Vector Ecology: Journal of the Society for Vector Ecology, 33(1), 76-88. https://doi.org/10.3376/10811710(2008)33[76:SPOAAD]2.0.CO;2

Vikram K, Nagpal BN, Pande V, Srivastava A, Gupta SK, Paul R, ... Telle O. 2015.
Comparison of $A e$. aegypti breeding in localities of different socio-economic groups of Delhi , India, 2(2), 83-88.

Wurisastuti T. 2013. Perilaku Bertelur Nyamuk Aedes aegypti pada Media Air Tercemar. Jurnal Biotek Medisiana Indonesia, 2(1), 25-32.

Ye YH, Chenoweth SF, Carrasco AM, Allen SL, Frentiu FD, van den Hurk AF, ... McGraw EA. 2016. Evolutionary potential of the extrinsic incubation period of dengue virus in Aedes aegypti. Evolution, 70(11). https://doi.org/10.1111/evo.13039

Yulidar Y, Wijaya F. 2015. Siklus hidup nyamuk Aedes aegypti pada skala laboratorium. SEL, 2(1), 22-28. 